\title{
Islamic Banking in Global Economic Context (Critical Studies of Operational System and Performance of Islamic Banking)
}

\author{
Jamal Abdul Aziz \\ (Faculty of Islamic Business and Economy IAIN Purwokerto, Jl. Jend. A. Yani No. \\ 40 A Purwokerto, Email:abdulaziz_jamal314@yahoo.co.id)
}

\begin{abstract}
Abstrak:
Berdasarkan kajian terhadap sejarah kemunculan dan sistem operasional Bank Islam beserta kinerjanya, penulis menyimpulkan bahwa konsep bank Islam pada hakekatnya merupakan bentuk islamisasi terhadap institusi perbankan. Hanya saja proses islamisasi yang terjadi baru sebatas pada aspek-aspek yang bersifat marginal, artifisial, dan formal-institusional, seperti penggantian istilah-istilah teknis dalam dunia perbankan dengan istilah yang berasal dari fikih muamalah, penghapusan bunga, dan penolakan terhadap praktekpraktek bisnis yang haram. Selebihnya, bank Islam tidak berbeda dengan bank konvensional. Dampak dari islamisasi yang kurang substansial-komprehensif tersebut adalah timbulnya kesan bahwa bank Islam justru 'terbelenggu' oleh konsep-konsep fikih klasik yang mendasarinya, di mana ia cenderung kontra produktif dengan tren bisnis moderen yang senantiasa menuntut efisiensi dan fleksibilitas. Agar tetap dapat survive di masa-masa mendatang, bank Islam perlu mengevaluasi diri secara terus menerus dengan selalu membuka diri terhadap berbagai kritikan yang dialamatkan kepadanya. Konsepsi yang terlalu berorientasi kepada doktrin harus diimbangi dengan kesadaran akan fakta-fakta dan tuntutan bisnis moderen, baik yang berskala lokal maupun global. Sementara itu cita-cita Islam yang ideal, seperti pemberantasan kemiskinan, pendistribusian kekayaan secara adil, dan penciptaan lapangan kerja, harus tetap menjadi orientasi utamanya.
\end{abstract}

Kata Kunci:

Riba, Profit and Loss Sharing, Mudlârabah, Murâbahah, Artificial Aspects of Islam

Abstract:

Based on the study of the history of emergence and operation of Islamic Bank and its system performance, the author conclude that the concept of Islamic bank is essentially a form of Islamization of the 
banking institutions. Such Islamization are limited to the marginal, artificial, and formal-institutional aspects, such as the replacement of technical terms in the banking world with a term derived from the figh al-mu'âmalah, the abolition of interest, and the rejection of unlawful business practices. Moreover, the Islamic bank is no different from conventional banks. The impact of such less substantial and comprehensive islamization is the perception that Islamic bank is precisely 'shackled' by the concepts underlying classical fiqh, where it tends to be counter-productive with modern business trends which are constantly demanding efficiency and flexibility. In order to remain able to survive in the future, Islamic banks need to evaluate itself continuously by always open to criticism addressed to them. The conception of Islamic banking oriented too much to the doctrine must be balanced with an awareness of the facts and the demands of modern business, both local and global scale. While the ideals of the Islamic ideal, such as the eradication of poverty, equitable distribution of wealth and job creation, should remain the main orientation.

\section{Keywords:}

Riba, Profit and Loss Sharing, Mudlaraba, Murabaha, Artificial Aspects of Islam

\section{Introduction}

Banking institution is one of the most vital instruments in modern economic system. It is hard to describe the existing of a modern society or country that operate its economic activities without it. The problem, however, emerges when there is a group of society, namely some Muslims, who feel that it is hard for them to involve themselves into any banking institutions in their life because of their belief that there are some elements in such institutions depriving some religious doctrines. One of them is the issue of interest. They believe that the interest is equivalent to ribâ which is strongly forbidden in Qur'ân and Sunna.

Since such circumstance Muslims have been facing a dilemma, on the one hand they are aware of the crucial role of banking institution in economic activities and they have been faced with religious doctrines that required them to avoid it, on the other hand. To handle such a dilemma some Islamic economic thinkers proposed a banking concept which was appropriate with Islamic 
doctrines and ethics. This idea spread to the Muslim world fast and then it was followed up by the founding of Islamic banks in many Muslim countries.

\section{History and Growth of Islamic Banks}

The founding of Islamic bank movements began in Pakistan in 1950s and then spread to the Arab world that was marked by the emerge of Mit Ghamr Savings Bank in Kairo in 1963. The bank established by Ahmad al-Najjar had operated as a rural social bank all along the Nil delta. Although it had operated in rural milieu and limited scale, it has been considered that it had an important role in developing Islamic financial and economic thinking. ${ }^{1}$ Under unfortunate political circumstances this bank then had been taken over by National Bank of Egypt and Central bank of Egypt in 1967, so it had operated on the basis of interest. In 1972 when the non-interest banking system was introduced again, Nasser Social Bank emerged as the substitute of the Mit Ghamr. ${ }^{2}$

In the preceding period PLS system ${ }^{3}$--- system that Islamic banking operation is based on --- itself had been operated in Pakistan and Malaysia in 1940s. They did manage collective pilgrimage in a non-conventional way (viz. non-interest system). ${ }^{4}$ After such two early pioneering efforts Islamic banks grew and expanded steadily fast. From only one Islamic bank over the world in 1970s increased to be nine banks in 1980s, i.e. Nasser Social Bank (1971), Islamic Development Bank (1975), Dubai Islamic Bank (1975), Faisal Islamic Bank of Egypt (1977), Bahrain Islamic Bank (1979), and International Islamic Bank for Investment and Development (1980). Between 1980 -

\footnotetext{
${ }^{1}$ David Baldwin and Rodney Wilson, "Islamic Finance in Principle and Practice (With Special Reference to Turkey)" in Chibli Mallat (Ed.), Islamic Law and Finance (LondonDordrecht-Boston: Graham and Trotman, 1988), 174; Muhammad Syafi'i Antonio, Bank Syariah: Dari Teori ke Praktik (Jakarta: Gema Insani Press, 2001), 19.

2 Zainul Arifin, Memahamai Bank Syariah: Lingkup, Peluang, Tantangan, dan Prospek (Jakarta: Alvabet, 1999), 11.

3 PLS (Profit and Loss Sharing) refers to a formula proposed by Muslim economic thinkers that was as substitution of interest concept in 'conventional' economics. In this system a lender did not impose any interest rates to a borrower, that is an enterpreneur, but both of them made a deal to share profits or losses in the enterprises of the later.

4 Antonio, Bank Syariah..., 18.
} 
1985 twenty four Islamic banks and other Islamic financial institutions were developed in Qatar, Sudan, Bahrain, Malaysia, Bangladesh, Senegal, Guinea, Denmark, Switzerland, Turkey, England, Jordan, Tunisia, and Mauritania. More Islamic banks or financial institutions are being established in almost all Muslim countries. Even in nonmuslim states where significant Muslim minorities exist, like USA and Australia, attempts are being made to set up Islamic financial institutions. ${ }^{5}$ International Association of Islamic Bank reported that there were more than two hundred Islamic financial institutions that operated over the world until 1999. ${ }^{6}$ Recently decade there were much more islamic banks all over the world.

In addition to individual banks, the banking system of Pakistan, Iran, and Sudan are apparently running on some Islamic basis. 7 Saudi Arabia was also in such a case. There was not any bank that was attributed by 'Islam' because all banks in it were required to operate in accordance with Islamic principles. IDB (Islamic Development Bank) is supposed to be the only one attributed by 'Islam', but it is not related to individual or private enterprises because it is actually a development assistant institution that provides non-interest funding for Muslim countries especially those with the lower incomes. ${ }^{8}$

The growth of Islamic banks in many Muslim countries have influenced Muslim people in Indonesia. In the early 1980s many discussions about Islamic banking were held in many places. The real initiative to found an Islamic bank occurred in 1991 when the notarial document of founding of Bank Muamalat Indonesia (BMI) firm was signed. But the bank began to operate on the first of May 1992. Until September 1999 BMI had more than 45 outlets spread in Jakarta,

5 Abdullah Saeed, Islamic Banking and Interest: A Study of the Prohibition of Ribâ and its Contemporary Interpretation (Leiden-New York-Koln: E.J. Brill, 1996), 15.

${ }^{6}$ Antonio, Bank Syariah...., 18.

7 Saeed, Islamic Banking, 15. Pakistan, for instance, since first of January 1985 had decreed a regulation that obliged all banks to operate without interest included foreign banks. PLS was maintained as substitution of interest. See Liaquat Ali Khan Niazi, Islamic Law of Contract (Lahore: Research Cell Dyal Sing Trust Library, 1990), 422-423.

8 Baldwin and Wilson, "Islamic Finance" ..., 175. 
Bandung, Semarang, Balikpapan, and Makassar. ${ }^{9}$ Since 1998, after the government released a new banking act (UU No. 10/1998) ${ }^{10}$, there was a wide trend to create the sharia branhces inside commercial (conventional) banks. ${ }^{11}$ This trend, of course, has a positive impact on the spread of Islamic banks in many regions. Bank Syariah Mandiri $(\mathrm{BSM})^{12}$ is the first state bank conversed to a sharia bank completely. Recently a number of commercial-private banks have opened shariabranches inside their institutions, among them are Bank IFI, Bank Niaga, BNI '46 (five branches), BTN, Bank Mega, BRI, Bank Bukopin, BPD Jawa Barat, and BPD Aceh. ${ }^{13}$

The emergence of Islamic banks has a close relationship with the struggle of Islamic thinking in the Muslim world at the end of nine-teenth century and the early twentieth century. Revivalist (tajdi>d) movements in the preceding era have caused bipolar Islamic thinking and movements in the modern era, namely neo-revivalism and modernism (including neo-modernism). While neo-revivalists seemed to have a fundamentalist character with simple issues such as prohibition of interest, compulsory veiling, and abolition of family planning program; modernists (and neo-modernists) prefer to carry on principle and philosophical issues, so that they were too difficult for common people to understand, such as educational reform, woman status in society, and representative governmental system. ${ }^{14}$

\footnotetext{
${ }_{9}$ Karnaen A. Perwatataatmadja and Muhammad Syafi'i Antonio, Apa dan Bagaimana Bank Islam (Yogyakarta: Dana Bhakti Wakaf, 1993), 84-85; Antonio, Bank Syariah..., 25. ${ }^{10}$ In addition to regulate many aspects of law and many kinds of enterprise of sharia banks, this new banking code also gave some guidence for commercial banks to create (open) a sharia branch inside their institutions even to converse to be a shariabank completely.

${ }^{11}$ In Indonesia the popular name of Islamic banking is 'bank syariah' (sharia bank). The choosing such name, of course, with considering many aspects especially socials and politics. In the new banking code this term or name is that been used.

12 It is one of the banks belong to Bank Mandiri.

13 Ibid., 26-27.

14 For detail information about history and map of revival and reform movements in Islam, see, for instance, Fazlur Rahman, "Islam: Challenges and Opportunities", in Alford T. Welch and Pierre Cachia (Eds.), Islam: Past Influence and Recent Challenge (Edinburgh: Edinburgh University Press, 1979), 315-330; idem, "Revival and Reform in Islam" in M. Holt, et. al. (Eds.), The Cambridge History of Islam, vol. 2 (Cambridge: Cambridge University Press, 1970), 632-656. Rahman declared that line demarcation between neo-revivalism and modernism isnot easy to draw. But we can identify some
} 
Despite both neo-revivalism and modernism influence on the structure of modern Islamic thinking, neo-revivalism has had more significant influence in developing the theory of Islamic banking. The theory had been developed to give a concrete and practical form of traditional interpretations of ribâ followed by neo-revivalists in the field of banking and finance. There were many factors that triggered the emergence of Islamic banks in the 1960s and the 1970s, among them, as Abdullah Saeed asserted, were: (i) neo-revivalist abolition of interest that was considered as ribô, (ii) abundant wealth of oil belonging to conservative gulf states, and (iii) the acceptance of traditional interpretation of ribâ by many Muslim governments which was then applied in their political decisions. ${ }^{15}$

\section{The Islamic Banking Concept}

Generally, the aim of founding of an Islamic bank is to promote and develop the applications of Islamic principles into the financial transactions, banking, and related business. The cores of the applied main principles are the abolition of interest in various kinds of business transactions, carrying out the lawful business in accordance to the sharia, and the payment of zâkah. The profit sharing scheme is used to substitute the interest. ${ }^{16}$

The operation of Islamic banking is based on a number of traditional Islamic principles of business transactions, namely: the deposit (wadli'a), the profit sharing scheme, the sale and purchase with profit margin, the operational and financial lease, and fee-based services. ${ }^{17}$ These are based on Islamic transactional concepts as expounded in figh al-mu'âmalah, so they are considered suitable with the sharia.

common characters. Among common characters belong to neo-revivalism are the struggle to westernization in Muslim community, advocation of the self-sufficiency of Islam and of Islam as a way of life, and the rejection of any reinterpretation of the Qur'ân and Sunna. Whereas the common characters of modernism are understanding Qur'ân wholistically, selective use of the Sunna, the exercise of systematic original thinking with no claim to finality, a distinction to be made between the sharia and fiqh, and the avoidance of sectarianism. See Saeed, Islamic Banking..., 7.

15 Ibid., 8.

16 Arifin, Memahami Bank Syariah..., 29.

17 Perwataatmadja and Antonio, Apa dan Bagaimana..., 88; Antonio, Bank Syariah..., 83. 
The depository principle is based on the wadlî́ $a$ concepts. ${ }^{18}$ There were two kinds of wadlîa, namely wadlî́a yad al-amânah (the trustee deposit) and wadlî́a yad al-dlamânah. In the first kind, the entrusted property or money is not permitted to be used (in any other business) so the acquiescent of entrusted properties (the bank) is able to impose financial responsibilities to the depositor. The compatible banking instrument with this kind of deposit is the save deposit box. On the contrary, in the second kind of wadlit $a$, the acquiescent of entrusted properties (the bank) is permitted to use it in any other business so the later may give or share the benefits with the depositor. But it is not the compulsory imposed to him (the later, bank) because this contract is based on trusteeship (wadli $\left.\hat{\imath}^{\prime} a\right)$, not on profit sharing scheme (mudlârabah), which the property may be withdrawn whenever the depositor wants. ${ }^{19}$ The compatible banking instruments with this kind of wadlì $a$ are the clearing account (giro) and saving (tabungan). ${ }^{20}$

The profit sharing scheme, as the second Islamic principle in this context, is based on the musyârakah ${ }^{21}$, mudlârabah $^{22}$, muzâra'ah ${ }^{23}$,

18 It was defined as a pure trustee from one person to the other or between the two corporations or more which must be maintained and then turned it back whenever the owner wants.

${ }^{19}$ Usually bank gives the bonus to the depositor however it is not be set as a condition before nor fixed on certain percentage in advance. It is really a pure policy of the bank. This rule needs to be noticed in order that the bonus is not considered as the interest.

${ }^{20}$ Antonio, Bank Syariah, 85, 87, 148-9. The difference between the giro and the saving is that the first can be withdrawn with a check or similar media whereas the second cannot.

${ }^{21}$ Musyâarakah is a cooperative contract between the two or more persons to operate an enterprise where each of them contribute financial funds or expertises. Profits and losses are shared among them in accordance to the initial agreement.

${ }^{22}$ Mudlârabah is a kind of cooperative contract where the first party provides financial funds on the whole, named shâhib al-mâl, whereas the other party manage it in an enterprise, named mudlârib. The profits are shared between the both parties whereas the losses are born by shâhib al-mâl along they occur by accident not caused by neglect of mudlârib.

${ }^{23} M u z \hat{a r r a}$ 'ah is a kind of cooperative contract in plantation realm between the owner of land and the worker where the first submit his or her land to the later to plant or cultivate. The repayment is in the form of certain shares of the harvest cro This contract is similar to the mukhâbarah only the difference is that in muzâra'ah the seed of plants is from the owner of land whereas in mukhâbarah it is from the worker. 
and musâqah ${ }^{24}$ concepts. However the most general applied principles are the first two, whereas the later two are applied especially in the financing of plantations by several Islamic banks. ${ }^{25}$

Usually, musyârakah is applied in the financing of a project where both client and bank provide financial funds. When the project has finished the client turns the financial funds back to the bank with its profit shares. In addition to project financing, musyârakah system can also be applied in equity financing to an enterprise in a certain term. If the term is up the bank divest its shares whether simultaneously or gradually. ${ }^{26}$

It so happens mudlârabah can be applied whether in equity financing or debt financing. There are two kinds of mudlârabah, namely mudlârabah muthlaqah (general investment) and mudlârabah muqayyada (special investment). In the first kind, mudlârib (bank) has the power to manage the capital without any determinations like the time, place, and kind of enterprises and services. Shâhib al-mâl (depositor) is a real investor, not a lender of bank like in the commercial-conventional banks. Each party must be ready to share whether profits or losses of the bank enterprises. Thus the bank, as shâhib al-mâl II, must be ready to share profits and losses of the entrepreneur (capital user), as mudlârib II. ${ }^{27}$ Whereas in the later kind of mudlârabah, mudlârib can manage the financial funds only in accordance with the stipulation of that shâhib al-mâl made. ${ }^{28}$

In the financing aspect, mudlârabah is applied to the periodic savings (tabungan berjangka) and special fixed deposit (deposito spesial). Whereas in the aspect funding it is applied in some products, such as trades and services, and the special investment (mudlârabah

${ }^{24}$ In musâqa contract the worker is only responsible to maintaining the plants. The repayment is, as well as mukhâbarah, in the form of percentage of the harvest cro

25 Antonio, Bank Syariah..., 90, 95, 99, and 100.

26 Ibid., 93. It was named musyârakah mutanâqishah (decreasing participation). See also Ibid., 167 and 168.

27 Ibid., 138. The bank with regard to the depositor is named mud\}a>rib but in its relation to the customer it is named shâhib al-mâl II. However the relationship between bank and its entrepreneur-customer is not only in the form of mudlârabah, it supposes to be in other forms such as corporation, sale and purchase, lease, and fee based services.

28 Ibid., 150-152. 
muqayyadah) that is the capital of the client which is allocated to certain enterprises as he or she wants. ${ }^{29}$

In the aspect of funding, unlike in the commercialconventional banks where the funding is extended through lending at a certain term with the interest, in Islamic banking it is extended through the trust financing scheme (mudlârabah) without interest. The profits are shared periodically in accordance with the deal made between them (the bank and his client) before. Upon maturity the client (as mudlârib) would have to turn the capital back into the bank as well as its shares of profits which have not been handed over before. ${ }^{30}$

The third principle, sale and purchase with the profit margin, includes bay' al-murâbahah ${ }^{31}$, bay' al-salam ${ }^{32}$, and bay' al-istishnấ. ${ }^{\prime}{ }^{3}$ Although there are many kinds of sale contracts in figh literatures, the three kinds of such sale were prominently developed as the basis of financing in the Islamic banking. In a bay' al-murâbahah the seller must tell the buyer about the cost price of the commodity and then determine the profit margin which will be calculated in the final price. In Islamic banking context it is applied in the form of Murâbahah KPP (Kepada Pemesan Pembelian) where the seller (bank) provides goods according to the buyer's order only. Generally it is applied in purchasing the invested goods through the letter of credit (L/C) for instance. The bay' al-murâbahah scheme is most prominently and excessively used in Islamic banking because it is simple and easy. ${ }^{34}$

Bay' al-salam in Islamic banking context embodies in the form of parallel salam that is the two salam contracts are done in sequence between the client (buyer) and the bank firstly and between the bank and the supplier secondly. It is generally applied in the funding of

${ }^{29}$ Ibid., 97.

30 Ibid., 161-162.

31 Bay' al-murâbahah is a trading that is based on the market price with the agreed additional amount of the profit margin.

$32 \mathrm{Bay}^{\prime}$ al-salam is purchasing goods which is submitted on the next time whereas the payment is in advance.

33 Bay' al-istishnâ' is a sale contract between seller and producer. The producer receiving an order from buyer will try to do according to the specifications of goods that have been agreed before. Both of them deal with the price and the way of payment. Compare with Niazi, Islamic Law.., 218.

34 Ibid., 101, 103, and 106. 
plantation with short term, approximately $2-6$ months. Through the bay' al-salam scheme the bank purchase the agricultural produces and then sell them to the others in the away of salam. In addition to the funding of plantation, it is also able to be applied in the industrial funding. ${ }^{35}$

Like bay' al-salam, bay' al-istishnâ' is also able to be done in sequence (parallel istishnấ), between the client (buyer) and the bank firstly and between the bank and the goods maker secondly. Even the latest party may do the contract with the other party to make such goods. However the bank is still the only party that is responsible to the client whereas the good maker is only responsible to the bank. So there is no juridical relationship between the client and the maker of goods ordered. The bank can take the profits from this contract. ${ }^{36}$

The fourth principle, operational lease and financial lease, includes al-ija $>r a^{37}$ (the operational lease) and al-ijârah al-muntahiya bi al-tamlik $k^{38}$ (the financial lease with purchase option). The latest scheme is more generally applied in the Islamic banking, because it is simpler and easier than the first whether in the aspect of bookkeeping or goods maintenance. ${ }^{39}$

The fifth principle, fee based services, includes al-wakâlah (delegation), kafâlah (guaranty), hawâlah (transfer service), rahn (mortgage), and qardl (soft and benevolent loan). In Islamic banking hawâlah could be applied in the factoring ${ }^{40}$, post-dated check ${ }^{41}$, and bill discounting. ${ }^{42}$ Whereas rahn is applied in two kinds of contract, firstly its function as additional contract where it is as mere collateral on the other contract. In this contract, the bank has the right to hold out

\footnotetext{
35 Ibid., 108-112.

36 Ibid., 113-116.

37 Al-ijârah is the leasing contract.

38 Al-ijârah al-muntahîyah bi al-tamlîk is a kind of leasing contract where in the end of the contract the goods change to be the lessee owner.

${ }^{39} \mathrm{Ibid} ., 117-119$. In fact the bank usually feels saver and easier in applying this scheme than of mudlârabah scheme. See also ibid., 167.

${ }^{40}$ Factoring means that the client who has lent to some one else transfer such debt to the bank to pay and then the bank dun it to the debtor.

41 Post-dated check is similar to the factoring, however the difference is that in the post-dated check, the bank is as a dunner without paying the debt first.

42 Bill discounting is similar to the hawâlah, if in the bill discounting the client must pay some fee, in the hawala it was not known.
} 
something belonging to the client. Bay al-murâbahah contract, for instance, needs the collateral to ensure the bank. Secondly, its function as an independent contract where it is similar to the conventional mortgage. 43

Furthermore the qardl can be applied in several kinds of contract below: 44

1. As a complement product of banking especially for the reliable client whenever he or she needs the advance money as soon as possible and he or she will repay it hastily.

2. As an assistant product of banking for the client that needs the money as soon as possible whereas he or she cannot draw his or her account because, for instance, it was in the form of fixed deposit (deposito).

3. As a banking product aimed to aid the extremely small enterprises or the social sector. ${ }^{45}$

Since the qard doesn't cause the financial profits, its funding in advance money may be taken from the capital of bank. Whereas the funding on extremely small enterprises and social sector derives from the charities of ummah (Muslim people) such as zakâh and shadaqah. Besides that it also may derive from the earnings of bank that were hesitated their lawfulness, for example the interest of L/C's collateral from the conventional bank. One of the arguments on it is the akhaff alal-dlararayn (keeping to the least disadvantages) principle. When the money of Muslim people is left 'idle' in the non-Muslim financial institutions, such as money of Arabian Muslims which were in the Jewish banks in Switzerland, it is supposed to be used in a way that disadvantage Muslim society. Therefore it is better to take such 'idle' money or funds and then it is used to the social benefit. 46

Thus this is a brief description of Islamic banking principles. Such principles serve as a basis for the overall operations of Islamic

\footnotetext{
43 The difference is that in the rahn the customer is not be burdened with interest, however what is charged is the cost of entrusting, keeping, and assessment. Whereas in the conventional mortgage it may accumulate according to its period of time. See ibid., 130 .

44 Ibid., 130.

45 For such special aim it was formed a special banking product too, namely al-qardl al-hasan (benevolent loan).

46 Ibid., 133.
} 
banking. So there is a close relationship between the principles and the operational system of Islamic banking. There are three primary elements in the operational system, namely (i) profit sharing as a basis character, (ii) debt financing mechanism, (iii) equity financing mechanism. As has been already seen, profit sharing is primarily based on mudlârabah where the Islamic bank become whether a saverclient partner or debtor-client partner. Since it is based on profit sharing, the profits that the client get fluctuate along time. ${ }^{47}$

The debt financing system in Islamic bank consists of (i) capital, (ii) depository, and (iii) investment. Capital is the financial funds derive from the owners of bank where it may be transferred through the musyârakah fî sahm al-syarikah (equity participation) in the form of shares of bank company. In the end of annual bookkeeping they will obtain the dividend. ${ }^{48}$ Whereas the depository derives from the client savings (tabungan), fixed deposits (deposito), and clearing (giro). The saving in Islamic banking may be based whether on wadli $\hat{\imath}^{\prime} a$ or mudlârabah contract, so it has the two alternative contracts offered to the customers. While the clearing is based on wadli $a$ contract, whether wadlî‘a yad al-amânah or wadlî́a yad al-dlamânah, only the fixed deposit is based on mudlârabah contract. In the investment financial funds derive from the client through mudlârabah scheme where he or she, as a shâhib al-mâl, portrays of the investor.

The equity financing system can be divided into two kinds, consumption and production financing. The later can be divided again into two kinds too, financing of financial funds (whether it is used to qualitatively or quantitatively increase productions or expand product markets) and investment financing (it is used to fulfill capital goods)..$^{49}$ Since it is so complicated, many aspects that must be managed and monitored, that investment financing in Islamic bank prefer to apply musyârakah mutanâqishah or al-ijârah al-muntahiyah bi altamlîk scheme than mudlârabah scheme. ${ }^{50}$

47 There are some factors that influence the quantity of profit shares, among them are the investment rate, the total invested funds, and the profit sharing ratio agreed at the initial contract. See ibid., 139-40.

48 Ibid., 146-7.

49 Ibid., 160-1.

50 Ibid., 167. 
In consumption financing Islamic banking provides several schemes, namely (i) bay' bî thaman âjil (sale and purchase with installment payment, it is one kind of bay' al-murâbahah) (ii) al-ijârah almuntahiyah bi al-tamlîk, (iii) al-musyârakah al-mutanâqishah (decreasing participation), and rahn.51

\section{Practical Islamic Banking: Some Critiques}

Islamic banking concept as has already been explained above in theory is good but empirically it still must be examined. The fundamental problem is concerned with the real aim of Islamic banking itself. In accordance with its name, Islamic banking should able to give significant contributions to economic purpose of Muslim society, such as battle against poverty, fair distribution of wealth, and making fields of endeavor. In fact Islamic bank is not able to give significant contributions when it is let operates in the hard competition with conventional banks. It will play the significant role when the banking operation based on the interest had been removed completely with Islamic financial system. ${ }^{22}$ If it is so, when will the Islamic financial system exist and in what form?

In addition to the problem above, there are some technical problems. Indeed the profit sharing mechanism---where it is regarded as the substitute of interest and the basis of the whole Islamic banking operations---, for instance, contains a number problems. Firstly, in fact it is applied on limited banking products not entire products. Various financing products based on sale-purchase and services obviously maintain fixed return for the bank, not PLS mechanism. ${ }^{53}$ Even such kinds of product banking just exactly dominate the financing product of Islamic banks. So it is not easy to apply the profit sharing mechanism on the entire financing products of banking institutions. ${ }^{54}$

51 Ibid., 168.

52 Niazi, Islamic Law..., 427.

53 Such as bay' al-murâbahah with the profit margin and al-ijârah with the cost of leasing.

54 This difficulty is recognized by Zainul Arifin, a practitioner of Islamic banking, who assert that the profit sharing mechanism is appropriately applied in the individual or interpersonal business whereas in the institutional business level like banking it become inefficient. Therefore he emphasized to the principle that all contracts are basically permitted as far as it does not involve ribâa and gharar. See Arifin, Bank Syariah..., 29. 
Secondly, according to this principle whether the bank or the client, as shâhib al-mâl or mudlârib, must be ready to receive whether the profit or the loss of their co-business in accordance with the percentage agreed among them in the initial contract. Then the problem is there a depositor who is ready to receive the loss, or the bank which is ready to bear the loss? In fact it has not been known that there was a depositor or bank that suffered losses. What occurs is that there is decreasing of profits received by depositors or banks. In such circumstances, is there a difference between Islamic banks that are without interest and commercial-conventional banks that are based on interest. Didn't both kinds of bank assume that money or funds loaned must bring about profits, so the lender or creditor has the right to receive profit shares or interest from the money loaned.

Beside that mudlârabah, the primary concept that the Islamic bank base on, is not really be freed from any shortcomings. Firstly, in the aspect of the philosophy of Islamic law mudlârabah contract is not an original concept derives from Islamic law but it is really from preIslamic traditions that was adopted by Muslims later, or at least it does not contradict the spirit of Islamic doctrines. Thus actually mudlârabah is a business contract that is not available in pristine Islamic doctrines. ${ }^{55}$ In addition to such historic explanation, Qur`an opposes ribâ prohibited as social exploitation with shadaqah encouraged as altruistic behavior, not opposes it with mudlârabah. ${ }^{56}$ Therefore mudlârabah should not have been regarded as the only Islamic concept where the Islamic banking is based on, so fundamental changes are always able to be done for the sake of the realization of a more Islamic and efficient banking institution.

Secondly, generally mudlârabah concept applied in the Islamic banking institutions in fact caused inefficient and risky business. In

\footnotetext{
55 See, for example, Saeed, Islamic Banking, 51-2. Ibn Hazm (d. 456/1064), for instance, asserted that every chapter in fiqh literatures has the basis fron Qur'an and Sunna excepts mudlârabah. Whereas Ibn Taymiyyah regarded that despite in the opinion of many Islamic jurists that the lawfulness of mudlârabah is based on certain reports attributed to some companions, however there is no authentic Sunna on mudlârabah attributed to the Prophet.

56 Because, as Ziaul Haque asserted, mudlârabah at certain degree, may be exploitative too like riba. See Syed Nawab Haider Naqvi, Islam, Economics, and Society, (London and New York: Kegan Paul Internasional, 1994), 128-129 in notes.
} 
the investment finance, for instance, since the Islamic bank bases its operations on mudlârabah it must be shâhib al-mâl that provides the entire funds for the entrepreneur, as mudlârib. If such a way is really operated there will be extra amount of money allocated to addition needs, such as evaluating the enterprise feasibility, monitoring its performance every time in order to be known its profits and losses so it receives true and fair shares of them, and so on. ${ }^{57}$ Therefore Islamic bank tends to avoid mudlârabah scheme in the investment financing and prefers to apply the musyârakah mutanâqishah scheme. 58 Thus mudlârabah concept is not applied completely.

Another problem is concerned with the zero rate of interest as the basis of Islamic banking. Despite Islamic bank formally is not based on interest, however several Islamic banking products offered are regarded, by some observers, similar or even equal to commercialconventional banking products based on interest. Among them is bay' al-murâbahah. The client who needs a unit of computer, for instance, will require the bank to buy it for him or her. Then the bank buy it 10 million rupiahs and tell such true price to the client. The bank then sell it to the client with marked-up price (murâbahah) agreed between them, with addition one million for instance, that will be paid in one year. If so, is such scheme different from one who borrow 10 million rupiahs in commercial-conventional bank with the interest rate is $10 \%$ in one year? Aren't such both schemes substantially equal. ${ }^{59}$

Another problem related to the problems above is the fact that business of Islamic bank is dominated prominently by the short term trade financing. ${ }^{60}$ Such circumstance relates with the fundamental

\footnotetext{
57 The explanation about the difficulties of mudlârabah application in modern and wide social system can be seen in Timur Kuran, "The Economic System in Contemporary Islamic Thought: Intrepretation and Assesment", International Journal of Middle East Studies, 18 (1986), 152-5; whereas about its application in Islamic banking can be seen in Saeed, Islamic Banking..., 58.

58 See Antonio, Bank Syariah..., 167.

${ }^{59}$ Compare with Aziz al-Kazaz commentary about murâbahah system that the Islamic banks apply in Dieter Weiss, "the Struggle for a Viable Islamic Economy" The Muslim World, 79 (1989), 53; Kuran, “The Economic System”..., 157.

60 According to Ibrahim Warde's study (2000) generally $80 \%-95 \%$ from the entire products of Islamic banks is murâbahah, whereas mudlârabah that constitutes a main concept of Islamic banking only less than 10\% from them. Chibli Mallat, "Commercial
} 
philosophy of Islamic banking that prohibits ribâa or interest in financial transactions but permits the profits received from the trade. As a consequence is the Islamic banks operate enterprises beyond the conventional bank customs where the Islamic bank becomes seller itself. It is not money that the Islamic banks provide, but they offer goods ordered by the client. 61

The entire financing of almost Islamic banks are extremely prevailed by such selling and leasing at the various kinds and fixed return for the bank. It was very little percentage of the entire financing that was based on the joint venture. If it has been done it is seldom applied in mid or long term enterprises. ${ }^{62}$

Thus, there is the gap inside the Islamic banking between theoretical and practical aspects. Islamic banking concept seems to reach artificial aspects, and has not reached substantial body yet. ${ }^{63}$ As a consequence is the appearing of banking institutions shackled by classical figh concepts enforced to apply in modern financial system. The interest regarded as prohibited ribâ that constitute the basis of Islamic banking caused this bank arduous to operate its function as the financial institutions. In the future it will be needed a comprehensively Islamic financial institution which able to give real contributions to the economic global context. The new concept must not be in the form of banking model because the banking concept itself was really 'un-Islamic' so it is impossible make it 'Islamic' completely. It is hard for Islamic banks as presents now to compete with conventional banks because the later has superiority much more than the first, such as infra structures, experiences, and business flexibility. These challenges must be noted by Islamic banking

Law in the Middle East: Between Classical Transaction and Modern Business" The American Journal of Comparative Law, 48, 1 (2000), 131.

61 Volker Nienhaus, "The Performance of Islamic Banks: Trends and Cases” Mallat, Islamic Law and Finance, 156.

62 It is supported by the fact that most deposits in Islamic banks are in short term whereas it is very risky to fund the mid and long term project with short term finance. Ibid., 157-9.

63 Nienhaus asserted that there is no fundamental difference between Islamic and conventional banks related to financing techniques, kinds of projects and enterprises that are properly financed. Of course there are some juridical differences between contracts applied in Islamic banks and those applied in conventional banks but in macro economic levels they are marginal differences. Ibid., 159. 
managers and its theoreticians in order to be competitive in the future.

\section{Concluding Remarks}

The banking system in the Islamic history has no precedent, so the existence of Islamic banking system as presents now really has no historic reference. Therefore it can be regarded as collective ijtihâd in the field of modern financial system. As an ijtihâd product of course it is still able to change and modify in accordance with requires to the efficiency and flexibility of the financial system. At the same time there is no compulsory upon every Muslim to follow such ijtihâd product so it is not wonderful that there are some Muslims who does not regard that the Islamic banking system explained above as somewhat really Islam requires.

Even though such circumstances no one can deny the fact that the efforts of Muslim economic thinkers to make an Islamic banking system has born fruits where the Islamic banks has grown in many places over the world. We should appreciate their good intentions and their ghîrah Islâmiyyah. As the pioneer effort it is natural that there are some shortcomings in the Islamic banking system because there is no great effort that is directly perfect. What should have to be is willingness to evaluate and improve such ijtihâd product, because there is no final ijtihâd product.

From the above discussion we know that apparently the islamization of banking institutions that has embodied in the form of Islamic banks has touched only the artificial and marginal aspects and has not reached the substantial one. It appears from the islamization tendency only in the institutional instruments such as removing technical terms in conventional banking with those derived from figh al-mu'âmalah or Arabic language, operating the lawful business only according to the sharia, nullifying the ribâ or interest, and the payment of zakâh. Since the banking concept cannot be separated from the interest, Islamic bank refusal to the interest make it suffering from disorientation, between as a financial institution and a trade one.

Beside that some basic concepts of Islamic bank derived from figh al-mu'âmalah seem to be enforced in banking application although Islam itself does not compel to apply such concepts formally in this institution. In the field of mu'âmalah (worldly affairs) Islam let us do or 
make everything freely including in modern financial institutions like banking. Therefore if such concepts are hard to apply, we can leave behind or modify them into certain form that fulfil modern economic requires, and of course without neglecting the sharia principles. Thus the islamization of financial institutions is not always meant as islamization of banking institutions. Muslim economic thinker can create other Islamic financial institutions where the spirit of Islamic doctrines can be kept in its operations in the one hand, and the requires of modern business such as simplicity, easiness, and efficiency can be provided completely, in other hand.

\section{BIBLIOGRAPHY}

Antonio, Muhammad Syafi'i. Bank Syariah: Dari Teori ke Praktek. Jakarta: Gema Insani Press, 2001.

Arifin, Zainul. Memahamai Bank Syariah: Lingkup, Peluang, Tantangan, dan Prospek. Jakarta: Alvabet, 1999.

Baldwin and Wilson, David and Rodney. "Islamic Finance in Principle and Practice (With Special Reference to Turkey)", in Chibli Mallat (Ed.), Islamic Law and Finance (London-DordrechtBoston: Graham and Trotman, 1988).

Kuran, Timur. "The Economic System in Contemporary Islamic Thought: Interpretation and Assessment", International Journal of Middle East Studies 18 (1986).

Mallat, Chibli. "Commercial Law in the Middle East: Between Classical Transaction and Modern Business", The American Journal of Comparative Law, 48, 1, 2000, p. 81-141.

Naqvi, Syed Nawab Haider. Islam, Economics, and Society. London and New York: Kegan Paul Internasional, 1994.

Niazi, Liaquat Ali Khan. Islamic Law of Contract. Lahore: Research Cell Dyal Sing Trust Library, 1990.

Nienhaus, Volker. "The Performance of Islamic Banks: Trends and Cases", Chibli Mallat (Ed.), Islamic Law and Finance LondonDordrecht-Boston: Graham and Trotman, 1988.

Perwatataatmadja and Antonio, Karnaen A. and Muhammad Syafi'i. Apa dan Bagaimana Bank Islam. Yogyakarta: Dana Bhakti Wakaf, 1993. 
Rahman, Fazlur. "Islam: Challenges and Opportunities", Alford T. Welch and Pierre Cachia (Ed.), Islam: Past Influence and Recent Challenge Edinburgh: Edinburgh University Press, 1979.

------. "Revival and Reform in Islam", P.M. Holt, et. al. (Eds.), The Cambridge History of Islam, vol. 2 (Cambridge: Cambridge University Press, 1970).

Saeed, Abdullah. Islamic Banking and Interest: A Study of the Prohibition of Riba and its Contemporary Interpretation. Leiden-New YorkKoln: E.J. Brill, 1996.

Weiss, Dieter. "The Struggle for a Viable Islamic Economy", The Muslim World, 79 (1989). 